\title{
Coronavirus and its Impact on Global Economy: Speeding up Structural Changes
}

\author{
Gributskaya O.V. \\ Siberian Federal University, Krasnoyarsk 660075, Russian Federation \\ *Corresponding author. Email: gribuskaya_olya@mail.ru
}

\begin{abstract}
Our world is currently undergoing the tremendous influence of the COVID-19 pandemic. The Coronavirus has interfered all spheres of people's lives and, of course, has not ignored the socio-economic field. Not only the number of COVID-19 victims is growing, but also the economic damage from measures taken by the governments to protect the population from the spread of the virus causes the global economic downturn. The Coronavirus has affected not only each state, but also the structure of the whole world economy. International trade, small and medium enterprises faced a number of difficulties after the border closures, the global supply chains of goods collapsed, the percentage of unemployed people increased, as well as human resources were no longer used effectively. The main objective of the study is to find out how the world economy will change in the post-coronavirus period and examine the main factors influencing its structural changes. In our research we used a number of methods such as data matching, expert opinion assessment and the case study. As a consequence, we concluded that we will witness a completely new era of economic development in the postcoronavirus period in which globalization processes will play a secondary role. Regionalization processes, as well as the use of new technologies, including artificial intelligence, will become the guardian of stable development without any serious economic losses.
\end{abstract}

Keywords: Coronavirus pandemic, world economy, deglobalization, economic turmoil, post-coronavirus

economy, labour market

\section{INTRODUCTION}

Globalization process is one of the main features of the XXI century. As the Coronavirus pandemic rages across the planet, keeping billions on lockdown and putting countries' economies under immense pressure, it becomes clear that our world, striving for political, economic and cultural unification, is unable to protect itself from large-scale threats to humanity. The crisis resulting from the spread of infection all over the world has made countries wonder whether they really need an interdependent global economy or not. The idea of an ideal interconnected world shaped by globalization now seems unrealizable. The relevance of this research is related to the tectonic changes in the structure of the world economy that are currently taking place as a result of the spread of the COVID-19. Thus, identifying the research gap we can say that no research to date has addressed this aspect of globalization processes, which cannot be predicted in advance. Therefore, there is a need to adapt national economies to new realities in a short time. It can be expected that the spread of the Coronavirus will force most countries to move to a new model of cooperation with countries, which is called «regional interaction». In addition, it can be assumed that a number of companies will rethink their policy in order to minimize possible risks from unforeseen circumstances, which will lead to remote management, as well as the use of artificial intelligence in all sectors of economics. To verify these hypotheses, we need to solve the following tasks:

analyze statistical data on the impact of COVID19 on the development of the world economic system;

- study expert opinion on the problem under research;

- $\quad$ make a forecast for the development of the world economy after the Coronavirus pandemic.

For conducting this study, we used various sources, such as scientific articles, reports by UNWTO, UNIDO, World Economic Forum, J. P. Morgan, as well as news sources.

\section{THE RESEARCH METHODS}

There is no doubt that the COVID-19 has caused tremendous damage to the global economy and financial markets. Declining of production activity and economic growth, reduction of the service industry, provision of remote services, increase of unemployment - all these examples are the negative consequences of the pandemic spread. However, it is necessary to accomplish a comprehensive research of the impact of the Coronavirus on the world economy for a real assessment of the damage caused, relying on the methods of different sciences. 


\subsection{Data matching method}

The essence of the data matching method is to compare certain indicators. This method is appropriate for economic analysis. For the study, we will take data for 2020 and 2019 to determine the size, the nature and the rate of change of the analyzed objects.

It is especially important for us to assess the impact of the coronavirus on the global economy. First of all, we should consider how the Index of industrial production (IIP) has changed under the influence of the COVID-19. To do this, we turn to the official data, which is presented by the United Nations Industrial Development Organization (UNIDO).

The Index of industrial production takes into account the indicators of manufacturing production, where the base year is $2015(2015=100)$. According to UNIDO's data, the world Index of industrial production (IIP) in January 2019 was 112.8, while in February 2020 the index was 102.6 [1]. At the same time, the United States Index of industrial production in June 2020 was 92.7 [2]. A similar situation can be seen by observing the United Kingdom's Industrial production index. The overall UK IIP in June 2020 was 86.6 [3].

However, a comparison of the Indices of industrial production is not enough to assess the pandemic influence on the world economy. In this regard, let us turn to other economic indicators.

It is not the first time the world economy has experienced serious turmoil. The world economic crisis of 2008-2009 had a great impact on the economy. The next step is to compare the impact of these events on the world economy in order to understand the scale of the current economic crisis.

The September 2020 data shows that the global Gross Domestic Product (GDP) is $\$ 61.924$ billion, while GDP in 2019 was $\$ 87.698$ billion. The World Bank data demonstrates that in 2008, the global GDP was $\$ 63.676$ billion, and because of the Global economic crisis, it fell to $\$ 60.396$ billion [4]. Despite the fact that the GDP data for 2020 is not final, we can still notice a considerable reduction of the world GDP.

Moreover, the border closures around the world in order to prevent the spread of the pandemic has led to a reduction in the number of passenger air travel. The number of international tourists could reduce by $60-80 \%$ in 2020 , the United Nations World Tourist Organization reports [1].

The same is true of the world labour market. There is a tendency to reduce the length of the working day. According to the International Labour Organization data, in the second quarter of 2020 , there was a $10.5 \%$ global reduction in aggregate working hours [1].

The Spanish statistics show that by the beginning of April, almost 900,000 people had lost their jobs after organizations closure in the middle of March. [5] The negative situation in the labor market is also a problem for African countries. More than half of jobs in Africa are at risk, the United Nations Economic Commission for Africa reports [5].

The borders closure influenced not only the tourism sector, but also the international trade. The World Economic Forum article's data shows that all companies except strategically important have closed in Italy because of the pandemic, as well as pharmaceutical companies are frightened of lack of the medicines supply, especially from India. This concern stems from the fact that India is one of the leading suppliers of medicines to many countries in the world [5].

In addition, the size of loans by different states is also growing because countries want to reduce the damage from the COVID-19. For instance, in February 2020, the US Treasury Department announced the need to borrow almost $\$ 3$ trillion in the second quarter of 2020 . Statistic data shows that this amount is 5 times more than ever before during a three-month period [5].

\subsection{Method of expert opinion assessment}

To consider the pandemic impact on the global economy, we also should use the method of expert assessments. Method of expert opinion assessment is a method that allows to make conclusions about the object of the study after referring to the points of view of specialists, politicians and other authorities. Since we cannot directly conduct a survey on the impact of the Coronavirus on the state of the world economy, we will use the official statements of experts on this issue. The next step is information processing. It will help us to draw a conclusion about the scale of the COVID-19 impact on the world economy.

Firstly, we examine the expert opinion of Antonio Guterres, the UN Secretary General. «I think we need to prepare a recovery and to prepare a recovery for a better economy, a more sustainable and inclusive economy. We do not need to replicate exactly the economy of the past. Many things will change, I would say irreversibly in our lives», Antonio Guterres reports to Euronews [6]. «It needs to be done in a coordinated way at the level of the G20 and then it needs to mobilise and I [estimate] that we will need about 2.5 to 3 trillion dollars to help the developing countries do the same», he also adds [6]. The UN Secretary General says about the huge financial investments that are needed to recover the economies of developing countries. Consequently, the COVID-19 is forming a new system of international relations. The process of globalization has contributed to the growth of interdependence of countries. Thus, according to the UN Secretary General, the only way to recover from the crisis is coordination of the world efforts.

For further studying of the Coronavirus impact on the global economy, we should analyze the expert opinion of specialists in the economic field. Bruce Kasman, chief economist at J. P. Morgan financial holding, believes that the COVID-19 will produce a global recession because all global markets are drastically reducing [7]. In addition, experts compare the consequences of the Coronavirus pandemic and the events of September 11, 2001. "The collapse in air travel demand brought on by these severe travel restrictions and the reluctance of travelers to fly has the potential to materially reshape global aviation more meaningfully than the events of September 11», says Jamie 
Baker, the U.S. Airline and Aircraft Leasing Equity Analyst at J.P. Morgan [7]

Ursula von der Leyen, the President of the European Commission, also concentrates on the scale of the economic damage from the Coronavirus. Her words can also be used for our research. Launching the initiative to create a European Union economic fund of recovery, the President of the EU Commission emphasizes that «the next sevenyear budget must be adapted to the new circumstances. We are not talking about billions, we are talking about trillions» [8].

\subsection{The case study method}

One of the vital methods for studying international relations is the case study method. The case study method is a method that allows you to study intensively a specific event in a specific context. This method allows not only to describe the research process itself, but also to predict its consequences. Therefore, this method is suitable for the subject of our research.

The research using the case study method includes several stages and is shown below.

1. Building a situation. In December 2019, the World Health Organization learned about the appearance of an unknown virus in China. The epidemic acquired a large-scale character, spread to the neighboring states, as a result of which the countries decided to introduce the principle of strident social distancing, to close borders, as well as to close some enterprises. The virus has greatly affected the state of the economies of the Asian countries. The World Monetary Fund (IMF) claimed that «economies in Asia would see no growth this year, for the first time in 60 years, with the service sector particularly under pressure» [5]. The IMF also announced that «the Chinese economy had contracted in the first quarter - the first time since quarterly records began in 1992» [5].

2. Statement of the research problem. The aim is to outline the strategy for economic recovery as well as prevention of similar economic shocks in the future, which some of the states in the world arena use nowadays or will use in the near future.

3. The beginning of the work with the case. We define the purpose of the study (to identify the causes of the crisis and focus on the scenarios for preventing economic turmoil), the time period (the end of 2019- 1 and 2 quarter of 2020), the object of study (the economic development) and geographical location (the world scale). Next, we analyze the case and fulfil the task.

\section{RESULTS}

\subsection{The impact on the global economy}

The statistics highlighted in paragraph 2.1 demonstrate that the COVID-19 pandemic has indeed had a major impact on the structure of the global economy. The global GDP and the Index of industrial production dropped significantly, the number of international flights decreased, the unemployment rate increased, the working hours also decreased, a huge number of businesses around the world were closed, as well as the service sector of the world economy suffered greatly. The results of collection of statistic data demonstrate that the world Index of industrial production in 2020 decreased by $10 \%$ [1], the IIP of the USA is $11 \%$ less compared to the data for June 2019 [2], as well as the UK IIP is $14.7 \%$ lower than in June 2019 [3]. The figure 1 shows the differences between the Indices of industrial production in 2019 and in 2020.

\begin{tabular}{lrcccc}
\hline & China & $\begin{array}{c}\text { North } \\
\text { America }\end{array}$ & Europe & $\begin{array}{c}\text { East } \\
\text { Asia }\end{array}$ & World \\
\hline Jan'19 & 126.4 & 105.0 & 107.4 & 103.8 & 112.8 \\
Feb'19 & 126.9 & 104.5 & 107.7 & 103.3 & 112.8 \\
Mar'19 & 129.7 & 104.5 & 107.6 & 103.1 & 113.7 \\
Apr'19 & 128.3 & 103.6 & 106.6 & 104.3 & 113.0 \\
May'19 & 128.9 & 103.8 & 107.3 & 105.5 & 113.6 \\
Jun'19 & 130.0 & 104.3 & 106.3 & 103.4 & 113.5 \\
Jut'19 & 129.9 & 103.9 & 106.1 & 105.1 & 113.6 \\
Aug '19 & 130.5 & 104.5 & 106.2 & 103.4 & 113.7 \\
Sep '19 & 131.7 & 103.9 & 106.2 & 105.2 & 114.2 \\
Oct'19 & 131.8 & 103.2 & 105.6 & 102.0 & 113.4 \\
Nov'19 & 133.4 & 104.2 & 105.8 & 101.0 & 114.1 \\
Dec'19 & 134.0 & 104.3 & 104.0 & 103.0 & 114.2 \\
lan '20 & 99.8 & 104.2 & 105.5 & 104.3 & 103.0 \\
Feb '20 & 100.3 & 104.2 & 104.9 & 102.0 & 102.6 \\
\hline
\end{tabular}

Figure 1 Industrial production index, base year 2015 [1]

The figure 2 demonstrates that the aggregate working hours in the second quarter of 2020 is 2 times more than in the first quarter of 2020, where estimated drop in working hours was $4,5 \%$ [1].

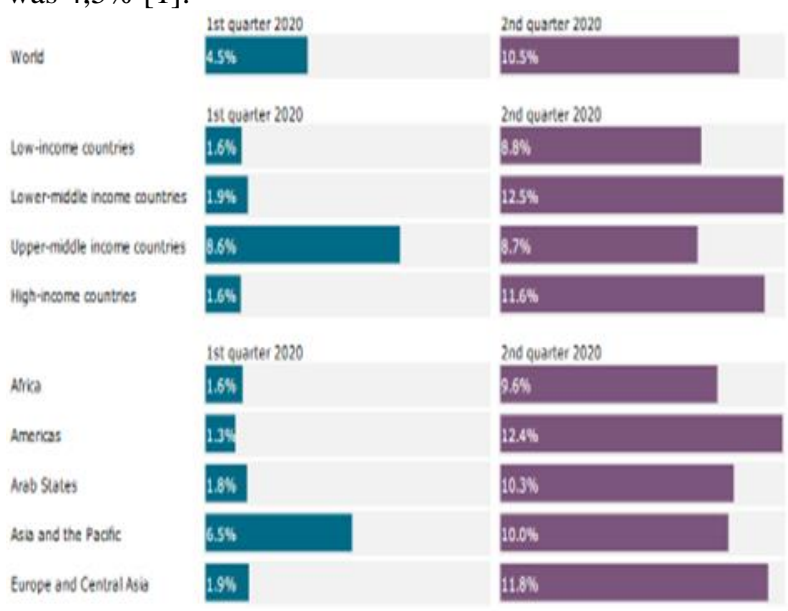

Figure 2 Estimated drop in aggregate working hours [1]

The size of loans by the US is 5 times more than ever before during a three-month period [5]. Method of expert opinion assessment shows that countries needed trillions of dollars in order to restore their economies.

Comparison of the impact of the Coronavirus on the socioeconomic field of our life with the consequences of the previous turmoils shows that the COVID-19 pandemic has 
a more devastating effect. Thus, the 2003 SARS epidemic reduces 0.5 percent to 1 percent of China's growth in 2003 and cost the global economy about $\$ 40$ billion (only 0.1 percent of global GDP) [9]. The debt of large companies in 2020 is also significantly higher than in 2003. For example, the debt of large American companies is about 10 trillion dollars in 2020, while in 2003 the debt was 2 times less (only 4.8 trillion dollars) [10].

\subsection{The emergence of new trends in the global economy}

We recognized that the Coronavirus pandemic considerably affected the changing of structure of the world economy. The analysis of the case in paragraph 2.3 led to the conclusion that the virus contributed to the emergence of new trends in international relations and in the world economy.

1. The Coronavirus revealed the weakness of a globalizing world. Such serious economic turmoils will lead to a shift towards regional forms of interaction in order to minimize economic losses.

2. The COVID-19 will lead to increased protectionist measures in a number of countries.

3. Due to the fact that the tourism sector brings a lot of income, as well as international passenger transportation remains temporarily inaccessible, there will be a revision of global economic value chains and a change in the role of tourism as a whole [10].

4. There will be a change in the approach to the labour market in the post-coronavirus future in order to make the process of work computer-assisted.

\section{DISCUSSION}

The result of our research is the discovering of a number of new trends in the development of the world economy. Its structural changes are motivated by the fact that such serious turmoils will force governments of all countries and a large number of companies to protect themselves in advance by creating a «safety cushion». We are talking not only about the financial protection of the economy, but also about the movement towards regional forms of international interaction. First of all, all countries think about their own national interests, where protection of the national economy will be a highest priority. The economic shock showed that despite the positive impact of globalization on global progress, this process has shown its weaknesses. Therefore, many international projects in the economic sphere will be implemented only when it is dictated by the national interest, not by globalization. So political deglobalization is one of the main features of the post-crisis world [11].

Globalization has contributed to the emergence of the international division of labour that has created a complex chain of interdependence [12]. Instead of producing something on the territory of their own country, it is more profitable for countries to purchase the required component abroad. As we can see from our research, the fear of being without the necessary medicines, food and other goods will force countries to focus on the development of small and medium-sized businesses. Thus, regionalization, along with protectionist measures, will also become a feature of the new system of economic relations. The global supply chains will be shortened to minimize economic losses.

There appeared a concept of a «new geopolitics of globalization» in international relations. Despite the desire to build a globalized world, countries can undertake harsh measures, such as a decision to block exports of goods that allies or neighbors may need [12]. A movement away from globalization will damage international cohesion but will help some individual states to minimize the risks of economic shocks. Therefore, the availability of certain resources or products in the possession of one country can become a bargaining chip against other countries where there is a shortage of necessary goods.

At the same time, we cannot speak about a complete rejection of globalization. Despite the admission of isolation measures to resist the COVID-19, a new center of power, which will lead the integration process, may appear in the world arena. This would-be leader is China, which is gradually improving the national economy after the pandemic [12]. China will not abandon such an ambitious project as the One Belt One Road project, so it will continue to build global chains linking the economies of other countries with the Chinese economy. That is why People's Republic of China, returning to its former life and gradually emerging from isolation, is helping other countries by supplying artificial ventilation devices, masks, protective suits and other goods [12].

The COVID-19 has influenced not only globalization processes, but also the role of the international tourism in the world economy. Firstly, countries will begin to pay attention to the development of domestic tourism. Secondly, some people will abandon the need for frequent international flights or trips by the land transport. Most of the organizations around the world, as well as the field of education, have been transferred to a remote format. The need to adapt to the spread of the Coronavirus has led to the fact that international forums were also held in the format of online conferences. For example, on March 26, 2020, a summit of G20 leaders took place in video format with the aim of taking coordinated actions to prevent the spread of the virus [13].

People realized that tourism contributes to the spread of the virus due to the mass movement of people around the world. The need to adapt to new conditions has shown that it is possible to continue the usual lifestyle, even if we need to abandon international flights. It does not only save financial resources, but also saves time and reduces the negative impact on the environmental situation around the world. Tourism is one of the main sources of greenhouse gas emissions and thus one of the factors indirectly increasing the risk of pandemics. Climate change increases the risk of outbreaks of pathogens and leads to mass migration [10]. We also noted the change in approach to the labour market as a new trend in the development of the world economy. The reduction in the number of employees under the influence of the Coronavirus, the growth of debts of many 
companies, the transfer of part of the staff to a remote format made employers think that sometimes having a person in the workplace is not required for the operation of a business. Most work places could disappear. The development of scientific and technological progress has led to the fact that new technologies or artificial intelligence (AI) can replace humans. For example, the outbreak of the SARS has accelerated the introduction of online technologies into the service sector. For example, Alibaba Company actively began to use delivery services in 2003. Now this company is one of the most famous companies offering online shopping services [11]. The scale of the spread of the Coronavirus has contributed to a serious increase in the workload of doctors. AI automate the work process in order to reduce the burden on healthcare workers. These technologies help to diagnose the disease at an early stage [14]. Artificial intelligence also accelerates the development of the Coronavirus vaccine. New technologies are being used to research medicines based on available data on the new virus, while developing a vaccine by humans without the use of AI can take years [14]. AI technologies are also used in the service industry. For example, robots deliver food and medicine to patients and bring the necessary equipment to doctors [15]. It does not only make the work of medical personnel easier, but also protects doctors from illness by adhering to the principle of social distancing.

Our research supported two hypotheses that were set at the beginning of the study. The impact of the Coronavirus on the economy can really force countries to switch to regional forms of cooperation. We are watching this tendency right now. The pandemic has changed the structure of world politics, as well as the approach to the labour market. The world economy will no longer return to the pre-coronavirus state, it is adapting to a new reality and acquiring new features. However, the problem with our study is that the COVID-19 has not disappeared yet and it is impossible to develop an accurate scenario for the development of the world economy. We do not know when the vaccine will be developed, when the economic decline will stop, so all the conclusions have the nature of forecasts.

\section{CONCLUSION}

1. Our findings suggest that the Coronavirus pandemic is the test for national health care systems. Nowadays almost every country has the opportunity to check whether its health care system stands by and sorts out the problems or not. And the answer for many countries is yes, their economies are still standing. Of course, it requires some particular changes both at national and international level, which leads to the structural changes of the world economy. 2. The Coronavirus pandemic has become a real test for the global economy as well. Despite the negative consequences of the spread of the virus (such as an increase in unemployment, the closure of enterprises, a drop in the level of welfare, the adoption of restrictive measures within individual states, the temporary inability to travel), our research still allows us to find some positive aspects in this turmoil. Any crisis is the engine of progress. The states began to adapt to current conditions and introduce new technologies to improve the quality of life. The COVID-19 has forced states to pay attention to the vulnerabilities of globalization. It will help them predict and overcome similar crises in the future.

3 . We are convinced that regionalisation processes are going to fast-forward because of the pandemic. Thus, it becomes clear that the pandemic speeds up certain structural changes of the global economy. We have been talking about Internet shopping or online publishing or building up local suppliers for more than 20 years and these processes still have been very slow in certain industries. Now it is happening. That's our reality. And the processes that were supposed to start, are not like a distant future anymore. For instance, the job market is changing, the businesses. Online businesses are here forever, and a lot of people will unlikely go back to work because they figure they can work from home.

4. Comparison of globalization and regionalization plays an important role in this research, since the states now need to make an important choice - to continue to interact globally or to defend their national interests. We believe that the states will create regional supply chains. We will have a Northern European, Asian etc. but not necessarily a global for the foreseeable future. It means that we will still have global supply chains, but we will gradually build a local or a regional backup. So, for a time, we will have both.

This study is of great importance because it allows people to study scenarios for the development of the world economy and undertake measures to reduce economic losses in the future.

\section{REFERENCES}

[1] How COVID-19 is changing the world: a statistical perspective (Report), Committee for the Coordination of Statistical Activities, 2020, pp. 20-26.

https://stat.unido.org/content/publications/how-covid19-is-changing-the-world\%253a-a-statisticalperspective;jsessionid=F66ED2D16443CA38C964E4B A08A8BDB0

[2] UNIDO statistics data portal. Impact of COVID-19 on manufacturing. United States of America (June 2020). Available at: https://stat.unido.org/COVID-19

[3] UNIDO statistics data portal. Impact of COVID-19 on manufacturing. United Kingdom (June 2020). https://stat.unido.org/COVID-19

[4] International tourist number could fall $60-80 \%$ in 2020, UNWTO reports, the United Nations World Tourist Organization, 07.05.2020.

https://www.unwto.org/news/covid-19-internationaltourist-numbers-could-fall-60-80-in-2020 
[5] The economic effects of COVID-19 around the world, World Economic Forum, 2020.

https://www.weforum.org/agenda/2020/02/coronaviruseconomic-effects-global-economy-trade-travel/

[6] We need a «war economy» to deal with COVID-19 crisis, UN chief Antonio Guterres tells Euronews, Euronews, 2020.

https://www.euronews.com/2020/03/25/coronavirusantonio-guterres-speaks-to-euronews-about-un-s-covid19-response

[7] Assessing the Fallout From the Coronavirus Pandemic, J.P. Morgan, 2020.

[8] EU Leaders Fail To Agree On Coronavirus Economic Recovery Program, National Public Radio (NPR), 2020.

[9] The Economic Impact of Coronavirus in the U.S. and Possible Economic Policy Responses, Center for American Progress, 2020.

[10] S. Gössling, D. Scott, C. M. Hall, Pandemics, tourism and global change: a rapid assessment of COVID-19, Journal of sustainable tourism 29(1) (2020) 1-19. DOI:

https://doi.org/10.1080/09669582.2020.1758708

[11] O. V. Buklemishev, Coronavirus crisis and its effects on the economy, Population and Economics 4(2) (2020) 13-17. DOI:

https://doi.org/10.3897/popecon.4.e53295

[12] Will the Coronavirus End Globalization as We Know It? Foreign Affairs, 2020.

[13] G20 to hold emergency video summit to discuss coronavirus, The Guardian, 26.03.2020.

[14] R. Vaishya, M. Javaid, I. H. Khan, A. Haleem, Artificial Intelligence (AI) applications for COVID-19 pandemic, Diabetes \& Metabolic Syndrome: Clinical Research \& Reviews 14 (2020) 337-339. DOI: https://doi.org/10.1016/j.dsx.2020.04.012

[15] Using artificial intelligence to help combat COVID-19. Organization for Economic Cooperation and Development, 2020. 